\title{
SINTESIS DAN KARAKTERISASI SUPERABSORBEN DARI SELULOSA JERAMI PADI \\ (Superabsorbent Synthesis and Characterization of Rice Straw Cellulose)
}

\author{
Wina Yulianti ${ }^{1}$, Farida Laila ${ }^{1}$, \\ ${ }^{1}$ Program Keahlian Analisis kimia Diploma IPB \\ ${ }^{2}$ Divisi Biofisika, Departemen Fisika FMIPA IPB \\ Diterima/disetujui : 22 Maret 2014/ 9 April 2014
}

\begin{abstract}
Copolymerization of cellulose from rice straw with acrylic acid and acrylamide produce biopolymer superabsorbent. Cellulose was purified from fat content by extraction with toluene:ethanol (2:1). Hemicelluloses and lignin were removal by using potassium hydroxide $5 \%$ and hydrogen peroxide $2 \%$ at alkaline $\mathrm{pH}$. Cellulose yield obtained was 21.56\%. FTIR spectra of lignin showed a loss of absorption at $1728 \mathrm{~cm}^{-1}$. Copolymerization was carried out at $65{ }^{\circ} \mathrm{C}$ under nitrogen athmosphere. Initiator and cross linking agent used were potassium peroxodisulfate and $N^{\prime} \mathrm{N}$-methylene bis acrylamide. Superbasorben resulted from this experiment showed the water swelling capacity after 24 hour for the water, solution of $100 \mathrm{ppm}$ of ammonium chloride, and urea respectively $387,11 \mathrm{~g} / \mathrm{g} ; 193,47 \mathrm{~g} / \mathrm{g}$ and $400,17 \mathrm{~g} / \mathrm{g}$.
\end{abstract}

Keywords : superabsorbent, rice straw, swelling capacity

\section{PENDAHULUAN}

Polimer superabsorben (SAP) atau hidrogel merupakan jaringan tiga dimensi yang terbentuk dari ikat silang polimer hidrofilik. Sifat hidrofilik SAP merupakan faktor yang menentukan kemampuan untuk menyerap dan mempertahankan sejumlah besar air di bawah tekanan tertentu ( $\mathrm{Li}$ et al 2012). Berdasarkan sifat pengontrolan perlepasan air SAP secara luas dimanfaatkan dalam bidang industri (Kosemund et al.,2009), kedokteran (Yu et al., 2005), pertanian (Xie et al., 2011), pengolahan air limbah (Guilherme et al., 2007). Pemanfaatan SAP dalam bidang pertanian bertujuan dalam pengontrolan pelepasan air dan pupuk yang merupakan tren baru untuk menghemat konsumsi pupuk dan untuk meminimalkan pencemaran lingkungan (Akelah 1996).

Akhir-akhir ini diperkenalkan SAP dari kopolimerisasi cangkok monomer vinil ke polimer alam, seperti kitosan (Sokker et al 2011; Anirudhan \& Rijith 2012), pati (Han et al 2009), selulosa (Ni et al 2009). Polimer alam digunakan untuk menggantikan polimer sintetik yang lebih sulit terurai di lingkungan dan harganya cenderung mahal (Liang et al 2009). Selulosa banyak ditemukan di alam, merupakan penyusun terbesar dinding sel tumbuh-tumbuhan, serat-serat kayu, serat-serat tangkai daun (Stevens 2007)

Berdasarkan data BPS (2012) total produksi jerami padi yang dihasilkan adalah 96,54 juta ton. Para petani umumnya membakar jerami padi tersebut. Asap yang disebabkan oleh pembakaran jerami padi mengakibatkan polusi udara yang serius. Pemanfaatan jerami padi sebagai sumber selulosa yang kemudian diaplikasikan sebagai SAP masih sedikit dilakukan. Purwaningsih et al. (2012) telah berhasil membuat biopolimer jerami padi. Selulosa jerami padi dicangkok menggunakan monomer akrilamida. Inisiator dan agen pengikat silang yang digunakan adalah amonium perokso disulfat (APS) dan N'N Metilena bis akrilamida (MBA). Kopolimerisasi dilakukan dalam suasana hampa udara menggunakan aliran gas nitrogen. Kapasitas swelling biopolimer 
yang diperoleh menunjukkan nilai yang rendah yaitu $8,16 \mathrm{~g} / \mathrm{g}$, sehingga perlu dilakukan modifikasi untuk meningkatkan kapasitas swelling.

Pada penelitian ini selulosa diisolasi dari jerami padi. Isolasi terdiri dari tiga tahapan yaitu tahap dewaxing untuk menghilangkan lemak, minyak dan zat ekstraktif lainnya menggunakan pelarut toluena dan etanol (2:1); tahap penghilangan hemiselulosa menggunakan kalium hidroksida $5 \%$ dan tahap terakhir proses delignifikasi menggunakan hidrogen peroksida suasana basa $\mathrm{pH}$ 12. Selulosa hasil isolasi dikopolimerisasi dengan akrilamida dan asam akrilat dalam suasana hampa. Inisiator dan pengikat silang yang digunakan adalah kalium perokso disulfat (KPS) dan MBA. Penambahan asam akrilat bertujuan untuk meningkatkan kapasitas swelling dan dapat menyerap senyawa ionik, sehingga untuk ke depannya dapat diaplikasikan dalam dunia pertanian. Superabsorben yang dihasilkan kemudian dikarakterisasi dan diuji kemampuan swellingnya terhadap air, amonium klorida dan urea,

\section{METODOLOGI}

\section{Alat dan Bahan}

Alat yang digunakan adalah peralatan gelas, oven, Spektrofotometri sinar tampak, hot plate, kondensor, tabung gas nitrogen, Fourier transform infrared (FT IR), Scanning electron microscopy (SEM),

Bahan yang digunakan adalah toluena, etanol, hidrogen peroksida, kalium hidroksida, gas nitrogen, Jerami padi, asam akrilat (AA), akrilamida (AAm), kalium peroksodisulfat, N,N-metilena bis akrilamida, natrium hidroksida, amonium klorida, urea.

\section{Isolasi Selulosa dari Jerami Padi}

Isolasi selulosa jerami padi mengacu pada Lu dan Hsieh, (2012) Jerami padi dicuci dengan air hangat untuk menghilangkan kotoran dan zat yang larut dalam air. Jerami padi bersih digiling dan disaring dengan saringan 40 mesh. Serbuk jerami padi $(30 \mathrm{~g})$ diekstrak terlebih dahulu dengan campuran toluena:etanol dengan perbandingan 2:1 (450 $\mathrm{mL})$ selama 6 jam dengan menggunakan metode Soxhlet suhu $50{ }^{\circ} \mathrm{C}$ untuk menghilangkan zat ekstraktif, lilin, pigmen, dan minyak. Jerami kemudian dikeringkan pada suhu $50{ }^{\circ} \mathrm{C}$ selama 24 jam. Hemiselulosa dihilangkan dengan cara penambahan $600 \mathrm{~mL} \mathrm{KOH} \mathrm{5 \%} \mathrm{pada} \mathrm{suhu} \mathrm{ruang} \mathrm{selama} 24$ jam dan pada suhu $90^{\circ} \mathrm{C}$ selama 2 jam, kemudian dikeringkan pada suhu $50{ }^{\circ} \mathrm{C}$ selama 24 jam. Lignin dihilangkan dengan cara penambahan larutan $\mathrm{H}_{2} \mathrm{O}_{2} 2 \%$ yang diatur pHnya sampai 12 dengan menggunakan $\mathrm{KOH}$ $4 \%$, suhu $40{ }^{\circ} \mathrm{C}$ selama 8 jam dan $90{ }^{\circ} \mathrm{C}$ selama 4 jam. Endapan kemudian dicuci sampai netral dan dikeringkan pada suhu $50^{\circ} \mathrm{C}$ selama 24 jam.

\section{Sintesis superabsorben jerami padi}

Sintesis polimer didasarkan pada percobaan Wu et al (2012) selulosa 0,35 g dimasukkan ke dalam reaktor berupa labu leher tiga yang dilengkapi dengan lubang pemasukan sampel, kondensor reflux dan selang nitrogen. Reaktor diletakan dalam penangas air suhu $65^{\circ} \mathrm{C}$. Gas oksigen dihilangkan dari reaktor dengan cara memasukan gas nitrogen kedalam reaktor selama 30 menit. KPS 3,97 mM dimasukkan ke dalam reaktor. Campuran AA, AAm dan MBA dalam aquades masing-masing $0,72 \mathrm{M} ; 0,48 \mathrm{M}$ dan 4,48 mM dimasukkan ke dalam reaktor setelah 15 menit, kemudian larutan ditera sampai $35 \mathrm{~mL}$ dengan akuades. Proses polimerisasi dijaga selama 1-2 jam pada suhu $65^{\circ} \mathrm{C}$. Gel yang diperoleh dicuci dalam akuades, kemudian dalam etanol dan berikutnya dalam aseton selama 24 jam pada suhu ruang. Gel yang diperoleh dipotong-potong. Kemudian dikeringkan pada suhu $65^{\circ} \mathrm{C}$ sampai beratnya konstan 


\section{Karakterisasi}

Selulosa yang diperoleh dikarakterisasi gugus fungsinya dengan FT IR, analisis morfologinya dengan SEM. Superabsorben yang diperoleh dianalisis gugus fungsinya dengan menggunakan FTIR.

\section{kapasitas swelling air, ammonium dan urea}

Pengukuran penyerapan larutan didasarkan pada percobaan Wu et al. (2012). Gel kering $(0,1 \mathrm{~g})$ dalam kain nilon dicelupkan ke dalam larutan, pada suhu kamar sehingga mencapai keserimbangan. Gel dipisahkan dari air yang tidak terserap. Kesetimbangan penyerapan air selama 24 jam (Qeq) dihitung dengan persamaan berikut:

$$
Q_{\text {eq }}=\frac{m_{2}-m_{1}}{m_{1}}
$$

$\mathrm{m}_{1}$ adalah massa gel kering, $\mathrm{m}_{2}$ adalah massa setelah penyerapan.

\section{HASIL DAN PEMBAHASAN}

\section{Isolasi Selulosa dari Jerami Padi}

Pemurnian selulosa dari jerami padi dilakukan dengan tiga tahapan. Tahapan pertama adalah penghilangan senyawa lipid, gula, protein serta zat ekstraktif lainnya melalui ekstraksi pelarut (tahap delipifikasi). Pada tahap ini proses ekstraksi menggunakan campuran pelarut toluena dan etanol dengan perbandingan 2:1. Tahapan yang kedua adalah penghilangan hemiselulosa dan lignin menggunakan natrium hidroksida. Perlakuan dengan basa dapat memutus ikatan antara lignin dan selulosa atau hemiselulosa melalui reaksi hidrolisis. Tahapan ketiga adalah destruksi lignin. Selulosa mengikat lignin pada $\mathrm{C}_{6}$. Pemutusan ikatan ini menggunakan larutan hidrogen peroksida yang berperan sebagai oksidator kuat yang dapat mengoksidasi lignin menjadi asam karboksilat (Zou et al., 2010).

Selulosa dari jerami yang dihasilkan berwarna putih (Gambar 1a). Hasil ini sesuai dengan yang telah dilakukan oleh Lu dan Hsieh (2012) yang menyatakan bahwa keberhasilan tahap isolasi selulosa dari jerami dilihat dari warna selulosa berwarna putih cerah bila dibandingkan dengan jerami padi awal berwarna kuning kecoklatan (Gambar 1b)

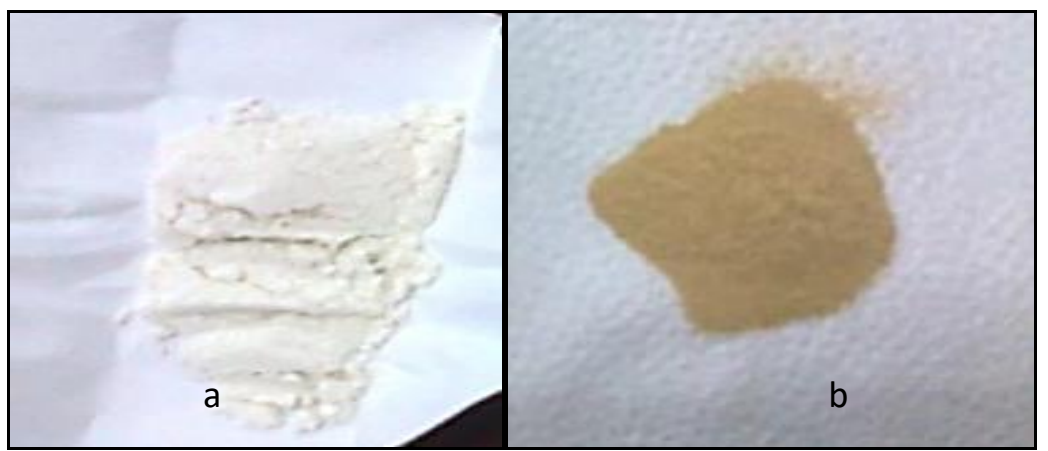

Gambar 1 selulosa jerami padi (a) Jerami padi (b)

Persen rendemen selulosa dari jerami padi adalah 21,56 \%. Persen rendemen selulosa ini lebih kecil dibandingkan dengan hasil penelitian yang telah dilakukan Lu dan Hsieh (2012) dengan persen rendemen 38,3\%; Purwaningsih et al. (2012) dengan persen rendemen $34,19 \%$. Perbedaan persen rendemen dipengaruhi oleh sumber jerami padi dan metode yang digunakan pada proses isolasi. 


\section{Karakteristik Jerami Padi}

Karakteristik selulosa jerami padi dibuktikan dengan analisis spektrum FTIR dan SEM. Spektrum serapan selulosa jerami padi dapat dilihat pada Gambar 2

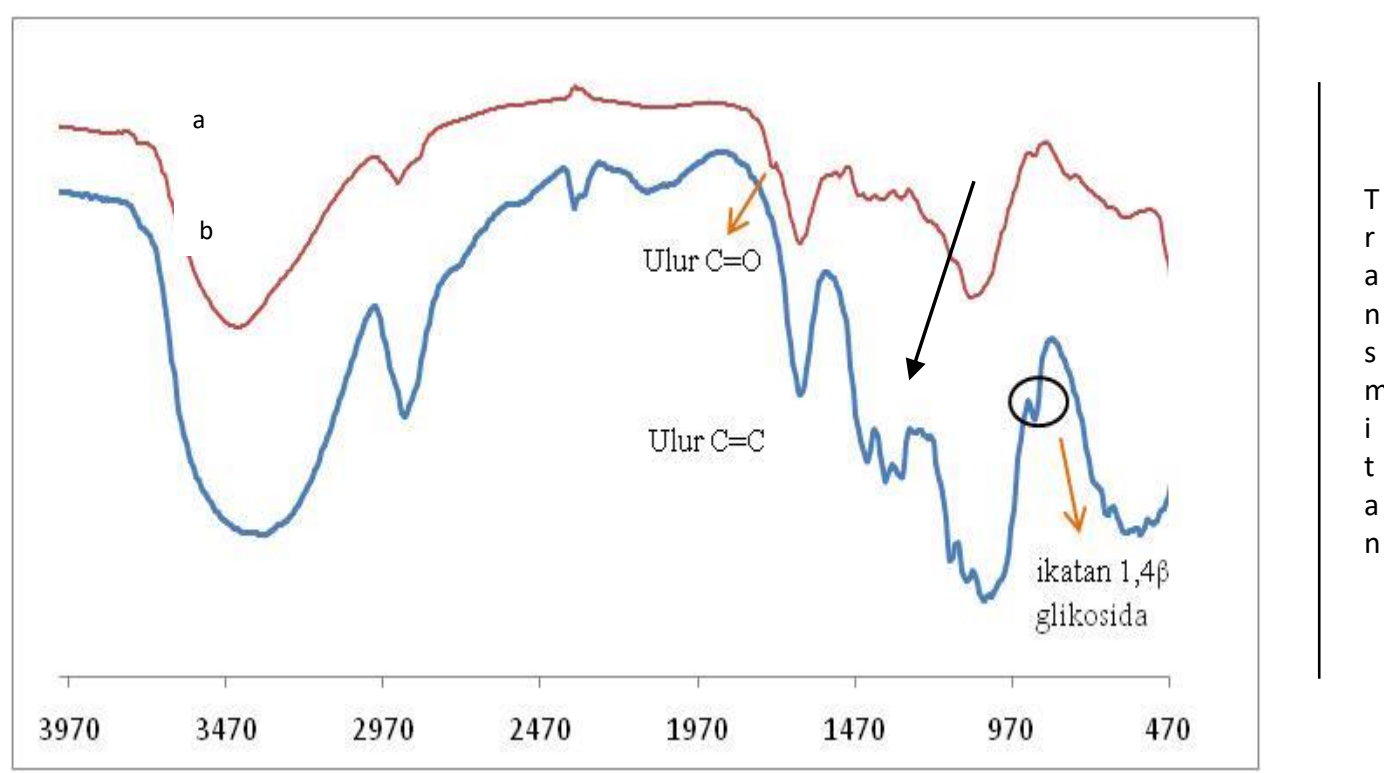

Panjang gelombang

Gambar 2 Spektrum FTIR (a) jerami padi, (b) selulosa hasil isolasi jerami padi

Spektrum jerami padi dan selulosa jerami padi menunjukkan serapan yang besar pada bilangan gelombang $3441 \mathrm{~cm}^{-1}$ menandakan adanya vibrasi ulur gugus $\mathrm{O}-\mathrm{H}$. Serapan pada $2924 \mathrm{~cm}^{-1}$ dari vibrasi ulur $\mathrm{C}-\mathrm{H}$ pada $\mathrm{CH}_{2}$. Puncak serapan lemah pada jerami di $1735,81 \mathrm{~cm}^{-1}$ menunjukan vibrasi ulur $\mathrm{C}=\mathrm{O}$ karakteristik ester pada lignin atau hemiselulosa, dan Vibrasi ulur aromatik $\mathrm{C}=\mathrm{C}$ pada lignin ditunjukan oleh puncak pada bilangan gelombang $1520 \mathrm{~cm}^{-1}$. Kedua spektrum tersebut tidak teramati pada selulosa jerami padi. Ikatan Vibrasi ikatan $\beta$ glikosida ditunjukkan dengan adanya serapan pada bilangan gelombang $895 \mathrm{~cm}^{-1}$ yang lebih kuat dibanding dengan jerami padi

Morfologi jerami padi dilindungi oleh matrik penyusun dinding sel (Gambar 3). Matrik penyusun dinding sel tidak teramati lagi pada selulosa jerami padi.

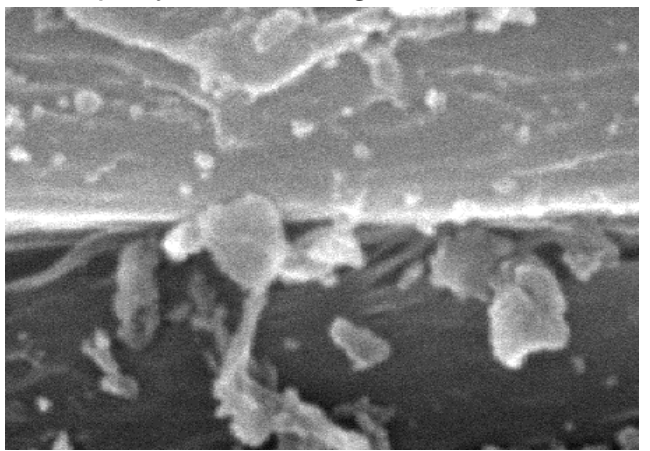

(a)

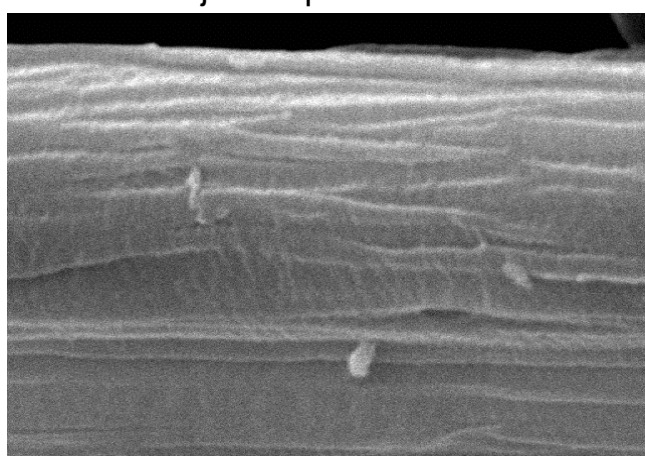

(b)

Gambar 3. Mikrograf SEM JSM jerami padi (a) dan selulosa jerami padi (b) pebesaran 500 kali 


\section{Kopolimer selulosa jerami padi dengan asam akrilat dan akrilamida}

Selulosa dari jerami padi menjadi kerangka utama (backbone) dalam reaksi pencangkokan. Mekanisme kopolimerisasi asam akrilat dan akrilamida ke dalam selulosa jerami terbagi menjadi tahap inisiasi, propagasi dan terminasi. Tahap awal reaksi adalah pembentukan radikal kalium persulfat membentuk radikal anion sulfat disebabkan oleh adanya pemanasan Radikal anion sulfatakan terbentuk pada suhu $60^{\circ} \mathrm{C}-65^{\circ} \mathrm{C}$ (Liang et al 2009). Radikal anion sulfat menyerang hidrogen dari gugus hidroksil yang terikatpada $\mathrm{C}_{6}$ pada selulosa dan mengambil atom hidrogennya sehingga terbentuk radikal makroselulosa

Pembentukan makroselulosa merupakan tahap inisiasi kopolimerisasi cangkok dan taut silang karena makroselulosa akan bereaksi dengan monomer membentuk radikal makromolekul lainnya Tahap propagasi dimulai saat radikal yang terentuk pada tahap inisiasi bereaksi dengan monomer lainnya membentuk radikal makromolekul Pada tahap terminasi,radikal makromolekul akan bereaksi dengan radikal makromolekul lainnya dan penaut silang MBA membentuk kopolimer cangkok dan taut silang

\section{Karakteristik selulosa jerami padi dengan asam akrilat dan akrilamida}

Serapan yang lebar sekitar $3100-3500 \mathrm{~cm}^{-1}$ menunjukkan vibrasi ulur $\mathrm{N}-\mathrm{H}$ dari Akrilamida yang tumpang tindih dengan vibrasi ulur O-H asam akrilat. Serapan $2900 \mathrm{~cm}$ 1 adalah vibrasi ulur $\mathrm{C}-\mathrm{H}$. Serapan 1728 menunjukkan uluran $\mathrm{C}=\mathrm{O}$ pada asam akrilat. Serapan $1666 \mathrm{~cm}^{-1}$ menunjukan pergeseran uluran $\mathrm{C}=\mathrm{O}$ disebabkan superposisi gugus amida pada bilangan gelombang $1659 \mathrm{~cm}^{-1}$ dan gugus $\mathrm{C}=\mathrm{O}$ dalam $\mathrm{COOH}$ pada bilangan gelombang $1718 \mathrm{~cm}^{-1}$ dan $1617 \mathrm{~cm}^{-1}$.

Pada bilangan gelombang $1575 \mathrm{~cm}^{-1}$ merupakan serapan karakteristik amida. Vibrasi ulur C-O-C spektrum superabsorben selulosa pada panjang gelombang $1057 \mathrm{~cm}$ ${ }^{1}$ sampai $1173 \mathrm{~cm}^{-1}$ menunjukkan serapan yang lebih lebar jika dibandingkan spektrum superabsorben monomer (Gambar 4)

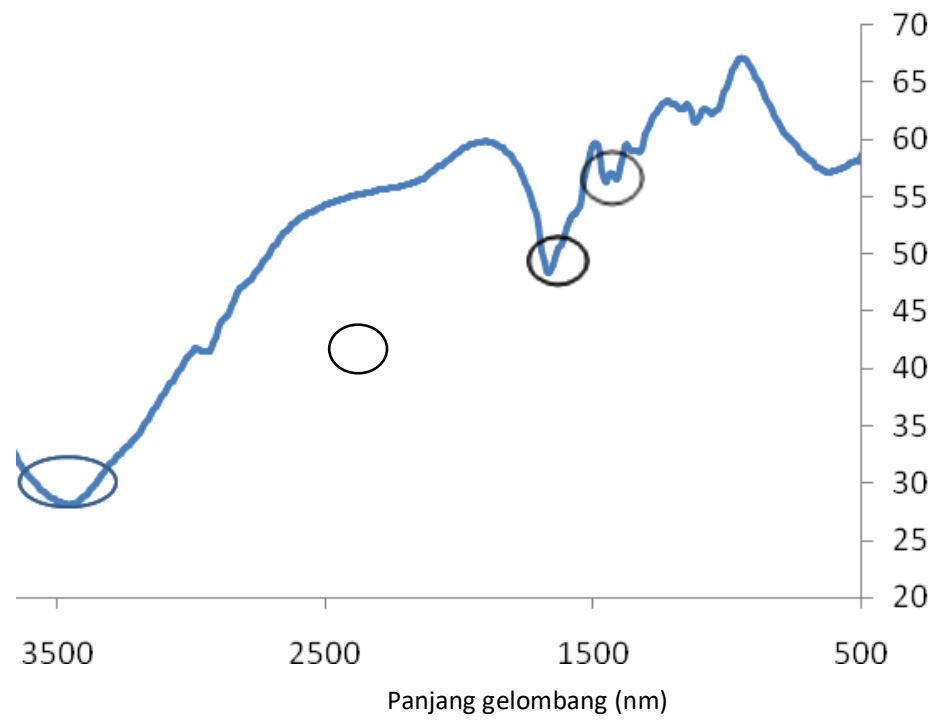

Gambar 4 Superabsorben seluıosa jeramı paaı

\section{Kapasitas swelling}

Kapasitas Sweeling superabsorben dalam waktu 24 jam dalam air, ammonium klorida dan urea berturut-turut adalah $387,11 \mathrm{~g} / \mathrm{g} ; 193,47 \mathrm{~g} / \mathrm{g}$ and 400,17 g/ (Gambar 5). 


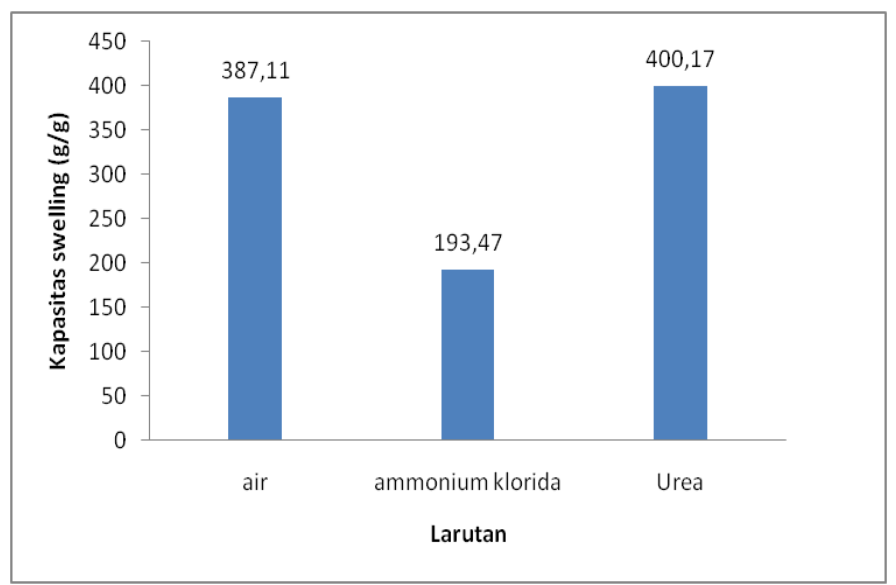

Gambar 5. Kapasitas swelling superabsorben selulosa jerami padi selama 24 jam

Kapasitas swelling larutan ammonium klorida lebih rendah dibandingkan dengan air dan larutan urea. Amonium klorida merupakan senyawa ionik sehingga apabila dilarutkan dalam air akan terurai menjadi ion-ion. Kandungan ion-ion yang ada didalam larutan akan meningkatkan tekanan osmotik larutan. Peningkatan tekanan osmotik larutan luar akan menurunkan perbedaan tekanan osmotik dengan superabsorben sehingga kemampuan superabsorben untuk menyerap air semakin menurun.

Berdasarkan Sadeghi dan Koutchakzadeh (2007) kemampuan Sweeling hidrogel akan berkurang dengan semakin bertambahnya jumlah ion yang terurai dalam air. Pada saat konsentrasi muatan di dalam gel lebih besar dibanding dengan konsentrasi muatan pada larutan luar akan menyebabkan hidrogel mengembang. Penambahan konsentrasi ion-ion dalam larutan luar menyebabkan perbedaan konsentrasi antara hidrogel dan larutan eksternal menurun dan hidrogel menjadi mengerut sampai konsentrasinya kurang lebih sama.

Kesetimbangan Sweeling pada larutan urea 100 ppm menunjukkan serapan yang paling tinggi dibandingkan air. Urea merupakan molekul netral yang memiliki gugus hidrofilik $\mathrm{NH}_{2}$. Penambahan urea dalam larutan eksternal menyebabkan semakin bertambahnya interaksi ikatan hidrogen antara superabsorben dan larutan eksternal yang menyebabkan Sweeling semakin besar (Liang et al., 2009; Zang et al., 2013)

\section{SIMPULAN}

Superabsorben selulosa jerami padi telah disintesis dengan teknik kopolimerisasi selulosa jerami padi dengan asam akrilat dan akrilamida. Selulosa jerami padi didapat dari tahapan ekstraksi lemak dengan toluena: etanol (2:1), penghilangan hemiselulosa dan lignin dengan menggunakan kalium hidroksida $5 \%$ dan hidrogen peroksida $2 \% \mathrm{pH}$ basa. Rendemen selulosa yang diperoleh adalah $21,56 \%$. Spektrum FTIR selulosa menunjukkan hilangnya serapan lignin pada $1728 \mathrm{~cm}^{-1}$. Kapasitas Sweeling superabsorben dalam waktu 24 jam dalam air, ammonium klorida dan urea berturut-turut adalah $387,11 \mathrm{~g} / \mathrm{g} ; 193,47 \mathrm{~g} / \mathrm{g}$ and $400,17 \mathrm{~g} /$.

Dalam penelitian ke depan perlu ditinjau beberapa hal diantaranya: penentuan konsentrasi ammonium dan urea yang diserap oleh superabsorben, kajian pelepasan kadar yang diserap superabsorben di tanah supaya bisa dimanfaatkan secara langsung dalam dunia pertanian

\section{DAFTAR PUSTAKA}

Akelah A. 1996. Novel utilizations of conventional agrochemicals by controlled release formulations. Materials Science and Engineering. C4, 83-98. 
Anirudhan TS, Rijith S. 2012. Synthesis and characterization of carboxyl terminated poly(methacrylic acid) grafted chitosan/bentonite composite and its application for the recovery of uranium(VI) from aqueous media. Journal of Environmental Radioactivity. 106, 8-19

Guilherme MR, Reis AV, Paulino AT, Fajardo AR, Muniz EC, Tambourgi EB. 2007. Superabsorbent hydrogel based on modified polysaccharide for removal of $\mathrm{Pb}^{2+}$ and $\mathrm{Cu}^{2+}$ from water with excellent performance. J. Appl. Polym. Sc., 105, 29032909.

Han X, Chen S, Hu X. 2009. Controlled-release fertilizer encapsulated by starch/polyvinyl alcohol coating. Desalination, 240, 21-26

Kosemund K., Schlatter H, Ochsenhirt JL, Krause EL, Marsman, DS, Erasala GN, 2009. Safety evaluation of superabsorbent baby diapers. Regul. Toxicol. Pharm, 53, 8189.

Li Q, Ma Z, Yue Q, Gao B, Li W, Xu X. 2012., characterization and swelling behavior of superabsorbent wheat straw graft copolymers. Bioresource Technology, 118, 204-209

Lu P dan Hsieh YL. (2012).Preparation and characterization of cellulose nanocrystals from rice straw. Carbohydrate Polymer, 87,564-573.

Ni B, Liu M, Lu S. 2009. Multifunctional slow-release urea fertilizer from ethylcellulose and superabsorbent coated formulations. Chemical Engineering Journal, 155, 892-898

Purwaningsih $\mathrm{H}$. et al. (2012). Rekayasa biopolymer jerami padi dengan teknik kopolimerisasi cangkok dan taut silang. Valensi, 2,489-500

Sokker HH, El-Sawy MN, Hassan MA, El-AnadouliBE. 2011. Adsorption of crude oil from aqueous solution by hydrogel of chitosan based polyacrylamide prepared by radiation induced graft polymerization. Journal of Hazardous Materials, 190, 359365

Stevens MP. 1999. Polymer Chemistry. Ed-3. New York: Oxford University Press

Wu F, Zhang Y, Liu L, Yao J. (2012). Synthesis and characterization of novel cellulose-gpoly (acrylic acid-co-acrylamide) superabsorbent composite based on flax yarn waste. Carbohydrate Polymer, 87, 2519-2525

Yu SH, Mi FL, Wu YB, Peng CK, Shyu SS, Huang RN, 2005. Antibacterial activity of chitosan-alginate sponges incorporating silver sulfadiazine: effect ofladder-loop transition of interpolyelectrolyte complex and ionic crosslinking on the antibiotic release. J. Appl. Polym. Sci. 98, 538-549.

Zhang Y, Wu F, Liu, Yao J. (2013) Synthesis and urea sustained-release behavior of an eco-friendly superabsorbentbased on flax yarn wastes. Carbohydrate Polymers, 91, 277- 28 